\title{
Cerebral Venous Thrombosis in Pregnancy
}

\section{Gebelikte Serebral Venöz Tromboz}

${ }^{1}$ Emergency Medicine Research Team, Tabriz University of Medical Sciences, Tabriz, Iran

2Medical Faculty, Islamic Azad University Tabriz Branch, Iran

ABSTRACT

Introduction: Although not a prevalent disease, cerebral venous thrombosis (CVT) has been considered relatively morbid. There is little research about CVT in Iran, but it is more likely during pregnancy and puerperium. Therefore, we conducted this study to determine the incidence and risk factors during pregnancy.

Methods: Twenty-eight patients were selected from the hospital archives. The files of pregnant patients who were diagnosed as CVT and who were admitted to the hospital between April 2015 and March 2018 were studied for demographic and gestational information. Statistical methods and software were utilized.

Results: The incidence of CVT was 14.52 cases per 100.000 pregnancies. Less than one third of the cases occurred in the postpartum period with a mean disease age higher than the pregnancy period. Immobility, primiparity, $0 \mathrm{Rh}+$ blood type or consanguineous marriage was found in most of the cases. Past medical histories were positive in 11 cases. Caesarean delivery or onset in the first postpartum week was found in most of the postpartum cases. magnetic resonance imaging managed to diagnose all cases, while computed tomography scan failed to do so. CVT was in the transverse sinus in most of the cases.

Conclusion: The study reveals some risk factors for CVT, such as immobilization, chronic hypertension, preeclampsia and caesarean section.

Keywords: Venous thrombosis, pregnancy, postpartum period

\section{Introduction}

In a study conducted in 2012, the annual incidence of cerebral venous thrombosis (CVT) was 1.32 per 100.000 persons (1). Sasannejad et al. (2) reported that CVT was more frequent during the fasting months, accompanied by the consumption of oral contraceptives (OCPs). CVT is three times more likely in women due to gender-related risk factors, e.g. consumption of OCPs and hormone replacement therapy (3). Pregnancy and postpartum period are also known risk factors for CVT (4).
\end{abstract}

\author{
(D) Alireza Ala1 , (D) Hamed Hojjatpanah1, (D) Samad Shams Vahdati1, (D) Sepideh Kazemieh²
}

öz

Amaç: Sık görülen bir hastalık olmasa da, serebral venöz tromboz (SVT) nispeten morbid olarak kabul edilmiștir. İran'da SVT hakkında çok az araștırma vardır, ancak hamilelik ve lohusalıkta daha olasıdır. Bu nedenle gebelikte insidans ve risk faktörlerini belirlemek için bu çalıșmayı yaptık.

Yöntemler: Yirmi sekiz olgu hastane arşivinden seçildi. Nisan 2015-Mart 2018 tarihleri arasında hastaneye başvuran ve SVT tanısı almış gebelerin dosyaları demografik ve gebelik bilgileri açısından incelendi. İstatistiksel yöntemler ve yazılım kullanıldı.

Bulgular: SVT insidansı, 100,000 gebelikte 14,52 idi. Olguların üçte birinden daha azı doğum sonrası dönemde görülürken, bu hastaların ortalama hastalık yaşı gebelik dönemindeki hastalardan daha yüksekti. Olguların çoğunda immobilite, primiparite, $0 \mathrm{Rh}+$ kan grubu veya akraba evliliği tespit edildi. Geçmiş tıbbi öykü 11 olguda pozitifti.

Postpartum olguların çoğunda sezaryen doğum veya doğum sonrası birinci haftada hastalık bașlangıcı bulundu. Manyetik rezonans görüntüleme tüm olguları teșhis etmeyi başarırken, bilgisayarlı tomografi taraması bunu yapamadı. SVT, olguların çoğunda transvers sinüslerde idi.

Sonuç: Bu çalışma, SVT için hareketsizlik, kronik hipertansiyon, preeklampsi ve sezaryen gibi bazı risk faktörlerini ortaya koymaktadır.

Anahtar Kelimeler: Venöz tromboz, gebelik, doğum sonrası dönem
The most frequent symptoms include headache, seizures and focal neurological deficits $(5,6)$. CVT is believed to be a significant cause of stroke, thus a high-mortality disease (7). The major predictors of outcome are a parenchymal lesion size $>6 \mathrm{~cm}$, bilateral Babinski signs, male gender, parenchymal hemorrhage and level of consciousness (8). Mortality has decreased in the recent years (9) and this may be due to a progress in diagnostic methods and earlier detections.

There is scarce reliable data about the medical histories and prognosis of patients with CVT, and they are generally based on the findings 
obtained by studying one facility or area with small samples (10). There is not enough recorded data about CVT in Iran. Due to the severe complications of CVT, this study was conducted in order to determine the incidence in pregnant women, to list the risk factors, including demographic and gestational factors, and to suggest an interventional approach for quick and proper management to be used in curative and palliative scheduling and decision making about these patients.

\section{Methods}

\section{Procedure}

This was a descriptive study on the files of pregnant patients admitted to the emergency department with a diagnosis of CVT between April 2015 and March 2018. Following authorization, we visited the hospital archives and obtained the list of pregnant patients diagnosed with "CVT" within the specified 3-year period.

First, a checklist of information gathering including demographics [age, gestational age, occupation, education, body mass index (BMI), etc.] and gestational factors (gravidity, number of abortions, family history of preeclampsia, history of preeclampsia in previous pregnancies, blood type, the mother's hemoglobin level, contraception method, complications of pregnancy, drugs used, history of hormone therapy, etc.) was assembled. Then, we visited the archives and filled out each checklist by carefully examining the corresponding file.

The acquired cases were evaluated according to inclusion and exclusion criteria, and a total of 28 patients and their data were evaluated. Total statistics of pregnancies submitted within the three years were extracted from the reports of the provincial health center.

\section{Target Population and Sample}

Due to the low number of pregnant patients with this diagnosis, the sample size was considered as all the pregnant patients visiting from April 2015 to March 2018 with the mentioned diagnosis, having acquired it during pregnancy or postpartum period. The sampling method was a headcount until completion.

\section{Inclusion Criteria}

- Pregnant patients with CVT confirmed by magnetic resonance imaging (MRI), CT scan or cerebral MR venography,

- Complete clinical and radiological data.

\section{Exclusion criterion}

- Coagulopathy before pregnancy.

\section{Statistical Analysis}

Data were analyzed using IBM SPSS v20 (IBM Corporation, Armonk, New York, US). The findings were analyzed using descriptive statistical methods [including tables, charts and calculation of mean and standard deviation (SD)], and chi-square test and Fisher's exact test were used for comparison of categorical variables. In all cases, the results were considered statistically significant if they had a $p$ value $<0.05$.

\section{Ethical Considerations}

- A warrant was obtained from the Office of the Vice Chancellor of Research (decision no: 54-12167, date: 28.09.2014). Written consent was obtained.

- The data collected from the files of the patients were kept completely confidential. For further assurance, the names of patients were removed from the checklists and patients were given ID numbers.

- The findings and results of the research were presented to the beneficiaries and published in coordination with them.

\section{Results}

According to the statistics obtained from the provincial health center, a total of 192.773 pregnant women were registered in three years; and since the hospital under study is a facility of referral for patients with this diagnosis, the incidence of CVT in this study was calculated as 14.52 cases per 100.000 pregnancies.

Of the 28 patients studied, 20 cases (71.4\%) were affected during pregnancy and eight cases (28.6\%) were affected in the postpartum period.

The status of the patients for each year they were referred to the center is stated in Table 1. The highest number of patients was from April 2017 to March 2018, followed by April 2015 to March 2016 and then April 2016 to March 2017. The mean number of patients diagnosed with CVT was 9.33 per year.

The mean age of the patients was $31.85 \pm 8.08$ years. The oldest age was 55 years and the youngest age was 20 years. In addition, the mean age was $30.9 \pm 7.12$ years in the group affected during pregnancy and was $34.25 \pm 10.25$ years in the group affected in the postpartum period.

Regarding education, patients were classified into 3 groups: illiterate, primary and secondary education, and higher education. Two cases were illiterate, 19 cases had primary or secondary education, and seven cases had higher education. Regarding occupational status, patients were classified into two groups. Twenty-four patients (85.7\%) were housewives and four patients (14.3\%) were employed.

Height, weight and BMI of the patients were also recorded. Mean, SD, minimum and maximum values for each case are stated in Table 2.

\begin{tabular}{|l|l|l|l|}
\hline Table 1. Pregnancy status of patients according to years \\
\hline Time of referral & Pregnancy & Postpartum & Sum \\
\hline April 2015 to March 2016 & 5 & 4 & 9 \\
\hline April 2016 to March 2017 & 5 & 1 & 6 \\
\hline April 2017 to March 2018 & 10 & 3 & 13 \\
\hline Total & 20 & 8 & 28 \\
\hline
\end{tabular}

Table 2. Mean height, weight and body-mass index of the patients

\begin{tabular}{|l|l|l|l|l|}
\hline & Minimum & Maximum & Mean & Standard deviation \\
\hline Height & 154 & 176 & 162.28 & 5.46 \\
\hline Weight & 50 & 86 & 69.82 & 8.31 \\
\hline BMI & 21.06 & 32.76 & 26.50 & 3.10 \\
\hline
\end{tabular}


The patients were investigated in terms of obstetrical history, gravidity, abortions and labors. Mean, SD, minimum and maximum values for each case are stated in Table 3. There was no history of abortions in 17 patients, while 11 cases mentioned at least one abortion. The percentages of these histories with the number of abortions are illustrated in Figure 1. Based on parity, the patients were divided into three groups: nulliparous, primiparous and multiparous. The frequencies of each are illustrated in Figure 2.

The patients were also investigated for history of OCP use. While 16 cases (57.14\%) did not mention any history of OCP use, 12 cases (42.86) mentioned it. In addition to OCP use, drug history of the patients was recorded separately. There was no history of drug use in 18 cases (64.3\%), while 10 cases (35.7\%) had a history of routine drug use. One patient had a history of multiple drug use (warfarin and fluoxetine). There were two patients with a history of warfarin use, one due to a CVT in the previous pregnancy and the other due to a CVT unrelated to pregnancy.

Smoking history, alcohol consumption and substance abuse were investigated. Twenty-five patients had a negative history, one case had a history of smoking and two cases had a history of infrequent alcohol consumption.

The patients were also examined based on blood type and $0 \mathrm{Rh}+$ was the most common blood type. The full results are stated in Figure 3.

The past medical history of the patients was also studied. Seventeen cases had no history. Two patients reported a history of chronic

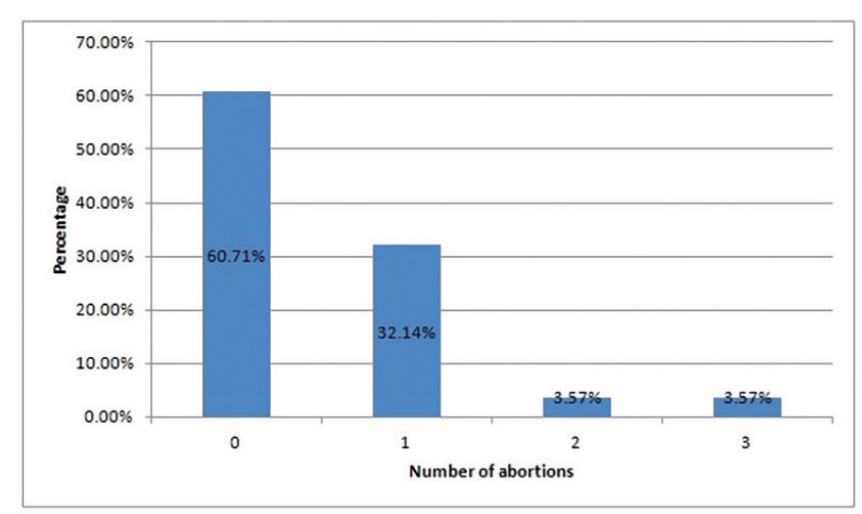

Figure 1. Number of abortions and percentages

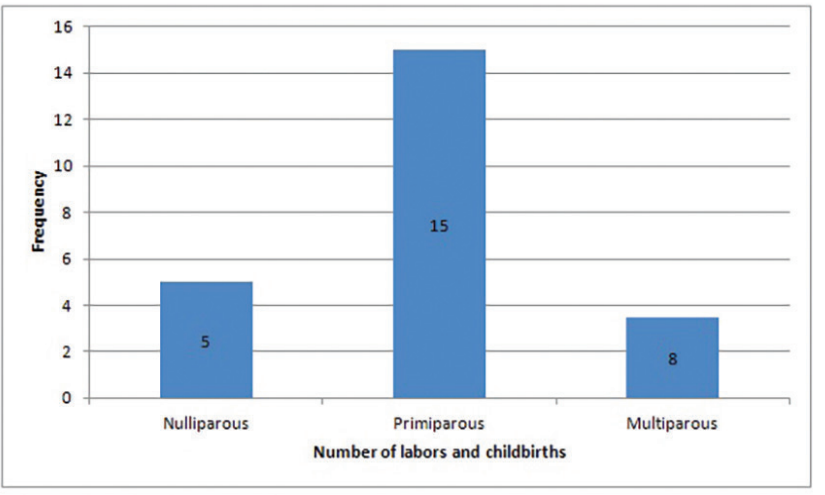

Figure 2. Number of labors and percentages hypertension (HTN) and two cases had a history of treated CVT. Other recorded histories are stated in Figure 4.

Platelet and hemoglobin levels of the patients were recorded and stated in Table 4. Two patients (7.14\%) had hemoglobin levels below $10 \mathrm{~g} / \mathrm{dL}$ and 26 patients (92.86\%) had hemoglobin levels between 10 and $14 \mathrm{~g} / \mathrm{dL}$. In addition, five patients (17.86\%) had platelet levels below $150.000 / \mu \mathrm{L}$, 22 patients (78.57\%) had platelet levels between 150.000 and 450.000 and one patient (3.57\%) platelet levels above 450.000 .

Seventeen patients (60.71\%) did not have coagulopathy, while seven patients (39.29\%) had coagulopathy. Familial history of thrombosis was investigated in the first-degree relatives of the patients. The results

\begin{tabular}{|l|l|l|l|l|}
\hline Table 3. Number of pregnancies, abortions and labors \\
\hline & Minimum & Maximum & Mean & Standard deviation \\
\hline Gravidity & 1 & 4 & 2.35 & 1.02 \\
\hline Abortion & 0 & 3 & 0.5 & 0.74 \\
\hline Labor & 0 & 3 & 1.17 & 0.81 \\
\hline
\end{tabular}

Table 4. Platelet and hemoglobin levels of the patients

\begin{tabular}{|l|l|l|l|l|}
\hline & Minimum & Maximum & Mean & $\begin{array}{l}\text { Standard } \\
\text { deviation }\end{array}$ \\
\hline Platelet & 22000 & 520000 & 223928.57 & 110141.29 \\
\hline Hemoglobin & 8.5 & 13.6 & 11.59 & 1.18 \\
\hline
\end{tabular}

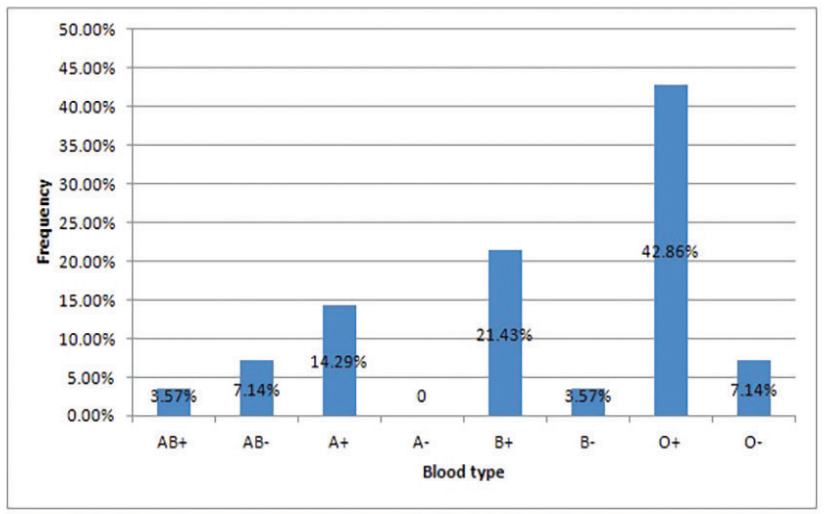

Figure 3. Blood types of patients and percentages

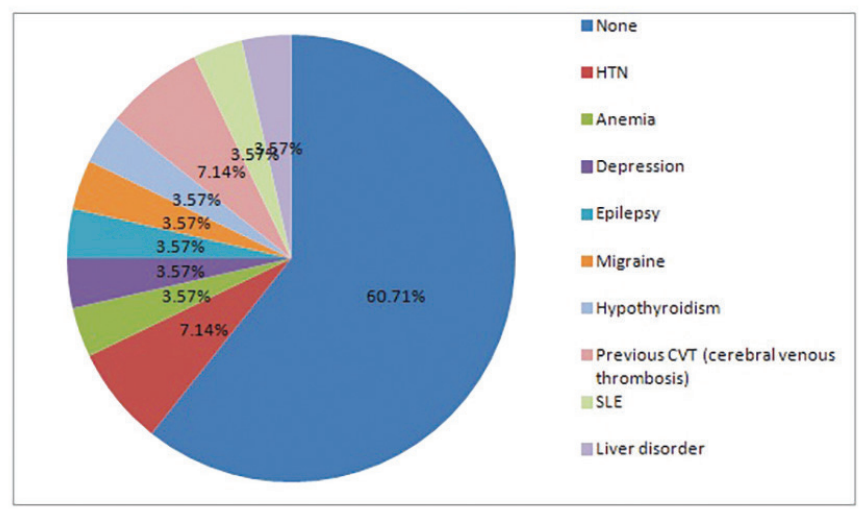

Figure 4. Past medical history of the patients 
were positive in five cases (17.86\%) and negative in 23 cases (82.14\%). Regarding consanguineous marriage, sixteen cases (57.14\%) had such marriage, while 12 cases (42.86\%) did not.

The seasons of referral were also recorded. Eight patients were referred in spring, six cases in summer, eight cases in fall and six cases in winter.

The diagnostic procedures requested for the patients were studied. MRI was used in 25 cases, all of which resulted in diagnosis. CT scans were performed in 16 patients, of which only one failed to diagnose. Some of these procedures revealed the veins with thrombosis, as illustrated in Figure 5. In one case, the patient refused MRI, leading to a CT scan that failed to find the specific area.

The outcomes of therapeutic measures taken until the patient was discharged were investigated. Twenty-four patients were discharged with general wellbeing. Two patients were discharged with personal consents and two patients died at hospital due to this condition. The outcomes according to pregnancy status at the time of referral are stated in Table 5. There was no significant difference in outcomes between the two groups $(p=0.76)$.

The following findings were obtained when eight postnatal patients were examined: Three cases were affected after vaginal delivery, while the other five were affected after caesarean delivery. The mean time from delivery to referral to the facility and diagnosis was equal to $6.87 \pm 1.80$ days, with a minimum of 4 and maximum of 10 days. This period was also divided into two sets, first week after delivery (six cases) and second week (two cases). One patient suffered from preeclampsia. One case had a history of CVT in her previous pregnancy. One case

\begin{tabular}{l|l|l|l|l|}
\hline \multicolumn{4}{|c|}{$\begin{array}{l}\text { Table 5. Final outcomes of the patients according the pregnancy } \\
\text { status }\end{array}$} \\
\hline & Well during discharge & Dead & Not defined & Total \\
\hline Pregnant & 17 & 1 & 2 & 20 \\
\hline Postpartum & 7 & 1 & 0 & 8 \\
\hline
\end{tabular}

\section{Table 6. Gestational ages by weeks and days}

\begin{tabular}{|l|l|l|l|}
\hline & Minimum & Maximum & Mean \\
\hline Days & 42 & 259 & 106.05 \\
\hline Weeks & 6 & 37 & 15 weeks and 1 day
\end{tabular}

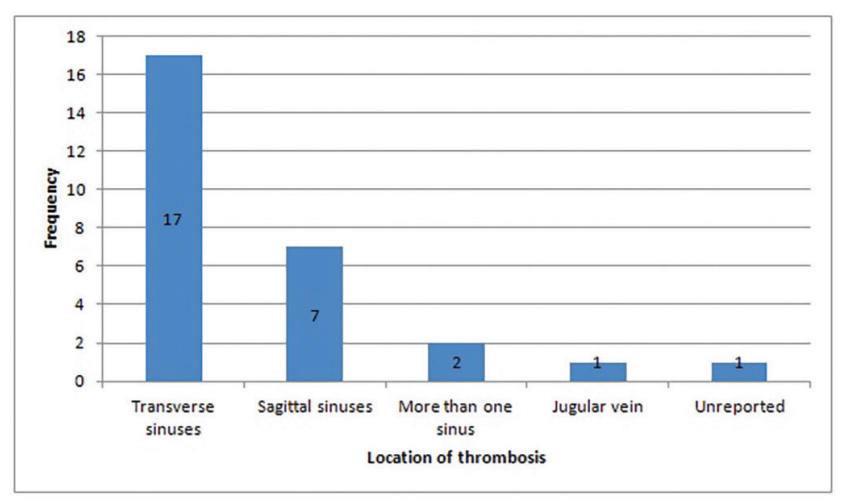

Figure 5. Involved veins and percentages managed to become pregnant by IVF. Two cases mentioned history of abortions in their previous pregnancies. Three patients did not specify any conditions in their current pregnancy or previous pregnancies.

Regarding 20 patients who were affected before delivery, the following findings were achieved: The gestational age by days and weeks was calculated and is stated in Table 6. Ten patients were affected in the first trimester, seven cases in the second trimester and three cases in the third trimester. There was no statistically significant difference in outcomes among patients with different trimesters $(p=1.00)$. The patients were also examined for pregnancy complication risks. Twelve cases had safe pregnancy. Five cases had risky pregnancies due to a history of abortion, one case due to stillbirth in a previous pregnancy, one case due to IVF and one case due to a diagnosis of HELLP syndrome.

\section{Discussion}

The incidence of CVT in our study was 14.52 cases per 100.000 pregnancies. In a study by Coutinho et al. (1) in 2012, the incidence was 1.32 per 100.000 person-years, while it was 2.78 among women between the ages of 31 and 50 years.

Liang et al. (11) reported that $60.47 \%$ of CVT cases in pregnancy occurred in the postpartum period. We found a lower rate of postpartum cases, which was $28.57 \%$. However, our cohort had a smaller size compared to the aforementioned study.

The mean age was $31.85 \pm 8.08$ years, close to what was observed in a study on stroke (12). However, the minimum and maximum values were higher in our study.

Most of the patients were housewives. Although there is not enough data to support immobilization as an independent risk factor for CVT, the high prevalence could indicate a role, even temporary. Engbers et al. (13) studied a larger sample and found immobility as a risk factor for venous thrombosis. However, our patients had lower ages compared to the minimum age of inclusion in the mentioned study (70 years), therefore not covering pregnant women.

In a study, it was proposed that obesity was a risk factor of CVT, apparently stronger when accompanied with OCP use (14). However, our study subjects had a normal mean BMI. Another study demonstrated short-term use of OCPs as a risk factor (10), but the association was not very strong in our study.

Most of the cases in our study were primiparous. Al-Hayali et al. (15) conducted a case-series study on 30 peripartum women with acute neurological emergencies received in the critical care unit and found most cases of CVT were multiparous compared to eclampsia, which was more common in the primiparous cases.

In a study, non-0 blood types were associated with venous thromboembolism (16), while the cases in our study were mostly $0 \mathrm{Rh}+$ Regardless of the Rh type, the 0 type was still dominant.

Miller et al. (17) conducted a study on the risk factors of stroke in pregnancy and found that infection, chronic HTN, prothrombotic state, coagulopathy and severe preeclampsia or eclampsia as the most common factors. Most of the patients in our study did not have any past 
medical history, while two cases had chronic HTN and two had previous CVT.

While a study by Liu et al. (18) showed an inverse relationship between lower hemoglobin levels and CVT prognosis, most of our cases had normal hemoglobin levels. However, the minimal normal level in our study was $10 \mathrm{~g} / \mathrm{dL}$, whereas the minimal level was $11 \mathrm{~g} / \mathrm{dL}$ in the mentioned study. It should be noticed that our mean level was close to the lower threshold in the mentioned study. In another study, anemia was also shown as a risk factor for CVT (19).

MRI had a 100\% diagnostic value in our study, whereas CT scan missed one patient. A review by Lee et al. (20) showed that CT scan was not specific. The transverse and sigmoid sinuses were presented as the most common site of thrombosis in a cross-sectional study by Coutinho et al. (1) investigating the most common areas of CVT (1). In our study, the majority of CVT cases were in the transverse sinuses, followed by sagittal sinuses.

Most of the cases in our study were generally well at discharge. In a review by Luo et al. (4), most of the participants had good prognosis after discharge, but unable to return to previous work.

Similar to the results of a report by Ehler et al. (21), most of the postpartum cases in our study occurred following caesarean section. While most of our postpartum cases had occurred in the first week, another study showed a majority of cases in the second and third weeks following delivery (22). Mean gestational age of the cases during pregnancy was 106.05 days or 15 weeks and 1 day. Fifty percent of the cases in our study were in the first trimester. However, no statistically significant relationship was found between the outcome and the trimester of occurrence in our study $(p=1.00)$.

This study was conducted with the patients in only one referral center. The data could not be generalized well. Due to the low prevalence of CVT, the sample had a small size. We suggest further studies with more hospitals and facilities and thus larger samples. Systematic reviews are also recommended.

\section{Conclusion}

CVT could afflict pregnant women with similar odds before or after delivery, though postpartum cases usually occur at slightly higher ages. Immobility could at least have a temporary role. Obesity does not have any association with CVT; the same could be said for OCP use. Gravidity is irrelevant to the risk of CVT. Blood type does not have any association either. Chronic HTN, anemia and preeclampsia are partially strong risk factors for CVT. Coagulopathy does not have any role either. CT scan is not an appropriate diagnostic method in CVT, as opposed to MRI. The transverse sinuses are common areas of occurrence. CVT has a generally well prognosis. Caesarean section is associated with a higher risk of CVT. The disease is likely in all three weeks after delivery. The same could be said for all trimesters during pregnancy. It is suggested to notice signs and symptoms of CVT in patients admitted 1 to 3 weeks after delivery, especially in those with a caesarean section. In addition, the pregnant patients should be educated about the symptoms and risk factors.
Ethics Committee Approval: A warrant was obtained from the Office of the Vice Chancellor of Research (decision no: 54-12167, date: 28.09.2014).

Informed Consent: Written consent was obtained.

Peer-review: Externally peer-reviewed.

Author Contributions: Surgical and Medical Practices - A.A., S.K., S.S.V.; Concept - S.K.; Design - S.S.V.; Data Collection and/or Processing - A.A., S.K.; Analysis and/or Interpretation - H.H., S.S.V; Literature Search - A.A., H.H.; Writing Manuscript - H.H.

Conflict of Interest: No conflict of interest was declared by the authors.

Financial Disclosure: The authors declared that this study received no financial support.

\section{References}

1. Coutinho JM, Zuurbier SM, Aramideh M, Stam J. The incidence of cerebral venous thrombosis: a cross-sectional study. Stroke 2012 43: 3375-7.

2. Sasannejad P, Mellat Ardekani A, Velayati A, Shoeibi A, Saeidi M, Foroughipour $\mathrm{M}$, et al. Cerebral vein thrombosis in women using short course oral contraceptive consumption. Iran J Reprod Med 2012; 10: 537-42.

3. Coutinho JM, Ferro JM, Canhão P, Barinagarrementeria F, Cantú C, Bousser MG, et al. Cerebral venous and sinus thrombosis in women. Stroke 2009; 40 : 2356-61.

4. Luo Y, Tian X, Wang X. Diagnosis and treatment of cerebral venous thrombosis: a review. Front Aging Neurosci. 2018. 10. PubMed PMID: 29441008. eng.

5. Ferro JM, Canhão P, Aguiar de Sousa DA. Cerebral venous thrombosis. La presse Médicale (Paris, France: 1983). 2016 Dec;45(12 Pt 2):e429-e50. PubMed PMID: 27816347. Epub 2016/11/07. eng.

6. Zuurbier SM, Coutinho JM. Cerebral Venous Thrombosis. Advances in Experimental Medicine and Biology. 2017; 906: 183-93.

7. Danwang C, Mazou TN, Tochie JN, Tankeu R, Bigna JJ. Global epidemiology and patterns of cerebral venous thrombosis: a systematic review and metaanalysis protocol. BMJ Open. 2018; 7; 8:e019939.

8. Barboza MA, Chiquete E, Arauz A, Merlos-Benitez M, Quiroz-Compean A, Barinagarrementeria F, et al. A Practical Score for Prediction of Outcome After Cerebral Venous Thrombosis. Front Neurol 2018; 9:882.

9. Coutinho JM, Zuurbier SM, Stam J. Declining mortality in cerebral venous thrombosis: a systematic review. Stroke 2014; 45: 1338-41.

10. Khomand P, Hassanzadeh K. A case-series study of cerebral venous thrombosis in women using short course oral contraceptive. Iran J Neurol 2016; 15: 92-5.

11. Liang ZW, Gao WL, Feng LM. Clinical characteristics and prognosis of cerebral venous thrombosis in Chinese women during pregnancy and puerperium. Sci Rep 2017; 6;7:43866.

12. Miller EC, Yaghi S, Boehme AK, Willey JZ, Elkind MS, Marshall RS. Mechanisms and outcomes of stroke during pregnancy and the postpartum period: A cross-sectional study. Neurol Clin Pract 2016; 6: 29-39.

13. Engbers MJ, Blom JW, Cushman M, Rosendaal FR, van Hylckama Vlieg A. The contribution of immobility risk factors to the incidence of venous thrombosis in an older population. J Thromb haemost 2014; 12: 290-6.

14. Zuurbier SM, Arnold M, Middeldorp S, Broeg-Morvay A, Silvis SM, Heldner MR, et al. Risk of cerebral venous thrombosis in obese women. JAMA Neurology 2016; 73: 579-84.

15. Al-Hayali RM, Al-Habbo DJ, Hammo MK. Peripartum neurological emergencies in a Critical Care Unit. Neurosciences (Riyadh). 2008; 13: 155-60. 
16. Sun X, Feng J, Wu W, Peng M, Shi J. ABO blood types associated with the risk of venous thromboembolism in Han Chinese people: A hospital-based study of 200,000 patients. Scientific Reports 2017 6;7:42925.

17. Miller EC, Gatollari HJ, Too G, Boehme AK, Leffert L, Marshall RS, et al. Risk factors for pregnancy-associated stroke in women with preeclampsia. Stroke 2017; 48: 1752-9.

18. Liu K, Song B, Gao Y, Zhao L, Fang H, Wang Y, et al. Long-term outcomes in patients with anemia and cerebral venous thrombosis. Neurocrit Care 2018; 29: 463-8.

19. Coutinho JM, Zuurbier SM, Gaartman AE, Dikstaal AA, Stam J, Middeldorp S, et al. Association between anemia and cerebral venous thrombosis: case-control study. Stroke 2015; 46: 2735-40.
20. Lee SK, Mokin M, Hetts SW, Fifi JT, Bousser MG, Fraser JF. Current endovascular strategies for cerebral venous thrombosis: report of the SNIS Standards and Guidelines Committee. Journal of NeuroInterventional Surgery 2018; 10: 803-10.

21. Ehler E, Kopal A, Mrklovský M, Kostál M. Cerebral venous thrombosis after a cesarean delivery. Acta Medica (Hradec Kralove). 2010; 53: 109-13.

22. Cantu-Brito C, Arauz A, Aburto Y, Barinagarrementeria F, Ruiz-Sandoval JL, Baizabal-Carvallo JF. Cerebrovascular complications during pregnancy and postpartum: clinical and prognosis observations in 240 Hispanic women. Eur J Neurol 2011; 18: 819-25. 